\title{
International conference "Alexander Chayanov: Differentiation and integration of economics and politics, science and art"
}

\author{
Eliane Fitzé
}

Eliane Fitzé, PhD Student, Chair of Slavic Literature, University of Fribourg. Rue du Criblet, 13, 1700 Fribourg, Switzerland. E-mail: eliane.fitze@unifr.ch

DOI: $10.22394 / 2500-1809-2021-6-3-191-195$

An interdisciplinary group of scholars participated in the online conference "Alexander Chayanov: Differentiation and integration of economics and politics, science and art", organized by the Chayanov Research Center, Russian Presidential Academy of National Economy and Public Administration, Gorky Institute of World Literature, and University of Fribourg. The conference brought together various approaches to the study of Chayanov's legacy in order to examine ways to differentiate and integrate its areas: from academic work - on agrarian economy, sociology and history - to literary writing. The examination of Chayanov's works in regard to the inseparable connection between these different areas provided an opportunity to take a new look at Chayanov's oeuvre as a whole. Moreover, the conference established a platform of 22 scholars interested in Chayanov's legacy, which open further possibilities for future collaboration.

Participants of the conference discussed the following issues: integration and differentiation of Chayanov's legacy and reflections on the peculiarities of interdisciplinary research; examinations of the relationship between economics, sociology, history and literature in Chayanov's life and work; challenges in the study of the life and work of Chayanov as a writer and scholar; uncovering of unknown facts and new materials in the study of his literary and scientific legacy; Chayanov's literary and scientific work in the context of the era; Chayanov and the utopian tradition; his communications and mutual influences.

The conference was opened by Dr. Alexander Nikulin (RANEPA, MSSES, Director of the Chayanov Research Center) and Dr. Nataliya Kornienko (Corresponding Member of the Russian Academy of Sciences, Head of the Department of Modern Russian Literature and Russian Literature Abroad of the Gorky Institute of World Literature). Nataliya Kornienko underlined the importance of interdisciplinary work in the study of the first quarter of the 2oth century by an 
192 interesting parallel between Chayanov's $A$ Short Course on Cooperation (1925) and Platonov's and Pilnak's Che-Che-O (1928): the former, a scholarly work, employs poetic images from literature, while the latter, a literary work, presents a thorough analysis of the social-economic state of the village. She praised the conference for its interdisciplinarity, internationality, and integration of younger researchers.

The first section "Alexander Chayanov. Biography and Local History" started with a presentation by Vera Bondarik (A. V. Chayanov's granddaughter) on Chayanov's biography which included new facts on Chayanov's life and showed him as a man of his historical time and environment. Dr. Tatyana Savinova (Russian State Archive of Economics) spoke about "The year 1918 in the life of A. V. Chayanov: Cooperation, literary activity, and anarchism" and highlighted the importance of the year 1918 as a watershed moment in Chayanov's life and work. Dr. Andrey Postnikov (Museum-Estate Arkhangelskoe) in the presentation "The Institute of Agricultural Economics at Moscow Yusupov Palace $(1927-1936)$ " examined the role of this palace in Chayanov's life and work (in 1927, he got it for his Research Institute of Agricultural Economics) and the role of Chayanov in the history of the palace. Dr. Alexander Nikulin, the discussant, praised all three presentations and raised questions about the life and work of Chayanov, such as about his incredible determination to his work and relentlessly positive attitude, the dire circumstances of his life, the paradox that Chayanov flirted with anarchism, but was a 'statesman', a proponent of the strong state, the role of aristocrats-philanthropists of the Yusupov family in Chayanov's life and work and in history of Moscow and Russia.

The second section "Chayanov. History and Economics" was opened by Dr. Stephan Merl (University of Bielefeld) with the presentation "Was Chayanov's concept of peasant agriculture under the Soviet rule realistic? The emergence of the 'kulturniki' as an answer to the 'Face to the Village' Policy of 1924-1925". Stephan Merl examined the figure of the 'kulturniki', the (middle) peasants that reacted positively to the 'Face to the Village' policy and tried to focus on accumulation on the basis of the cooperative movement promoted by Chayanov, which, however, did not save them from dekulakization. Dr. Lyubov Ovchintseva (RANEPA) spoke about "The evolution of Chayanov's views on the national economic significance of peasant farms". Her comparative analysis of Chayanov's texts of the early and late 1920s revealed the changes in his concept of the peasant economy as a labor economy with special incentives for development. In the presentation "How can I thank you, Bulgakov!': A. V. Chayanov as a follower of the Moscow school of political economy", Dr. Igor Kuznetsov (RANEPA) examined the contacts of Chayanov with Sergey Bulgakov, who was one of the forerunners of the organization-production school: from him Chayanov seems to have borrowed the name for his protagonist in one of his fan- 
tastic-romantic short stories. The section's discussant Dr. Tatyana Savinova praised the presentations as three different interdisciplinary approaches to Chayanov's life and work, but added some critical comments for future research such as a need for a more thorough and wholesome analysis of the academic atmosphere at the Moscow University, which had a huge impact on three generations of scholars, and of the specific context of the 1920s.

The third section "The Literary Context of Chayanov's Works" focused on the culturological approaches to Chayanov's works. In the presentation "The ephemeral and elusive nature of certain meta-real characters and images in Alexander Chayanov's romantic novels in the light of the literary and historical context of his time", Dr. Giulia Gigante (Brussels Free University) examined the ephemeral in Chayanov's romantic short stories and identified common images in the writings of Chayanov and Aldo Palazzeschi. Dr. Muireann Maguire's (University of Exeter) presentation "A. V. Chayanov and his literary peers: Tracing 2oth century Russian gothic" identified some common tropes and literary strategies in the works of Chayanov, Pavel Muratov, and Alexander Amfiteatrov. They all refer to the past to create an estranging effect, which is a typical strategy of the English Georgian era. Dr. Natasha Grigorian's (University of Konstanze) presentation "Alexander Chayanov's The Journey of my Brother Alexey to the Land of Peasant Utopia: Thought experiments and utopian heroes" considered Chayanov's work as a 'counterfactual thought experiment'. The section's discussant Eliane Fitzé (University of Fribourg) had several questions to each participant, for instance, about the difference between thought experiment and utopia, the epoch awareness of Chayanov and his peers, and the link between the past and the ephemeral, the past and the uncanny in Chayanov's literary works.

In the fourth section "Chayanov's Futurology: Politics and Art, History and Contemporaneity”, Dr. Chris Monday (Dongseo University), in the presentation "Alexander Chayanov's techno-anarcho utopia and the film 'Albidum: A Victory over the Sun' (1928)", uncovered information about the film (Chayanov wrote its scenario), and contextualized the film within the history of the Soviet cinema, culture and politics, making an emphasis on Chayanov and narodnichestvo. Amgalan Sanzheev (Tokyo University of Foreign Studies), in the presentation "Toward a study of Chayanov's political thought: On the role of 'tyranny' and the concept of 'societal struggle' in peasant utopia", conducted a thorough philosophical-political analysis of Chayanov's utopian novel and the fictional newspaper excerpts 'Zodiac' in its appendix to explain the relationship of 'tyranny' and 'societal struggle'. Dr. Alexander Nikulin's (RANEPA, MSSES) made a presentation on "Chayanov and Orwell: Rethinking the alternatives of 1984". He examined the parallels and differences in the life and work of Chayanov and Orwell, focusing on the most striking resemblances: rejection 
194 of authoritarianism and search for anti-authoritarian alternatives. Dr. Ilya Gerasimov (Ab Imperio) made a presentation on "Poor Alexander Chayanov': Why Chayanov is of interest in 2021", in which жизнь proposed a provocative thesis that Chayanov was of interest mostly for examining specific ideas of the early 20 th century, but the search for ready-made revelations in Chayanov's works would lead into a trap. The section's discussant Dr. Igor Kuznetsov (RANEPA) added comments and requests for further clarification to all presentations.

The second day of the conference started with the fifth section "Aesthetics and Narratives in Chayanov's Literary Works". Dr. Dmitriy Nikolaev (Gorky Institute of World Literature) opened it with the presentation on "The aesthetics of peasant utopia in the book and in life (Alexander Chayanov's 'Journey')", especially on the creation of the peasant utopia. The second presentation "English allusions in Chayanov's romantic novels" was made by Dr. Olga Kaznina (Gorky Institute of World Literature) who highlighted the references to the English literature and culture in Chayanov's utopian novel and romantic short stories. In the presentation "The third Rome will be a Rome of cooperatives': Contextualizing Alexander Chayanov's The Story of the Hairdresser's Doll (1918)", Eliane Fitzé (University of Fribourg) analyzed Chayanov's playful allusion to the 'third Rome' myth in regard to the Italian cooperative farming as transferred to the Russian context. The section's discussants Dr. Muireann Maguire (University of Exeter) and Olga Pavlova (Krasnodar State Institute of Culture) asked different questions, such as about the relation of the 'third Rome' myth to socialism, Chayanov's aesthetics (unexpected shifts between fictional and nonfictional genres), the nature of his literary utopia in general.

The sixth section "Chayanov's Poetics and Literary Strategies" started with the presentation by Olga Pavlova (Krasnodar State Institute of Culture) on "The legacy of A. V. Chayanov and the virtual culture of the information society (on the prognostic potential of the social-cultural projection of The Journey of My Brother Alexey to the Land of Peasant Utopia)". Olga Pavlova argued that Chayanov's utopian novel anticipated the manipulative technologies of today's information society, which she showed on the role of utopia and written culture throughout history. Michel Niqueux (Université de CAEN-Normandie) made the presentation on "Chayanov's last utopia (A Possible Future for Agriculture, 1928) compared with The Journey of my Brother Alexey to the Land of Peasant Utopia)" to show their genre difference (a work of literature and a theoretical treatise) in different historical contexts. Elizaveta Apalkova (MSU) talked about "A typology of characters in Chayanov's romantic tales" to present different protagonists in Chayanov's romantic short stories as following both typical romantic tradition and complex archetypal images. The section's discussant Dr. Natalya Mikhalenko asked questions on different aspects of the presentations, such as about the concept 'al- 
ternatives' in Chayanov's works, the parallels between Chayanov and Nikolay Fyodorov, and Chayanov's historiographical work on Moscow.

During the lunch break, the participants of the conference took a virtual tour of the exhibition "Reconstruction of Utopia" in the "Park" Gallery (Moscow) organized by the gallery's director Nikita Spiridonov.

The seventh section "Chayanov and Literary Utopia" started with the presentation by Dr. Anastasya Gacheva (Gorky Institute of World Literature, N. F. Fyodorov Library No. 180) on "Projecting the future: Chayanov's The Journey of My Brother Alexey to the Land of Peasant Utopia and the futurological ideas of the Russian cosmologists in the 1920s and 1930s". She highlighted the links between Chayanov's utopia and the Russian cosmologists' ideas, mainly of Aleksandr Gorsky, Nikolai Setnitsky, and Valeriyan Muravyov, three followers of Fyodorov. The presentation by Valeriya Fedotova (Krasnodar State Institute of Culture) explained "The specifics of the implementation of carnival poetics in Chayanov's neo-romantic novel The Venetian Mirror, or the Bizarre Adventures of the Glass Man". She showed how Chayanov's short story repeats motives of romantic literature and carnivalesque in the protagonist's consciousness. The presentation "The philosophy of life-creation in the works of A. V. Chayanov" given by Dr. Natalia Mikhalenko (Gorky Institute of World Literature) revealed how many characters in Chayanov's fictional writings had characteristics of their author with the concept 'life-creation': Chayanov seemed to consider different ways to confront fateful circumstances in a rapidly changing world. The section's discussants Dr. Nataliya Mikhalenko and Eliane Fitzé asked questions about different aspects of the presentation, such as about the role of chaos in the cosmist thought and of the free will in Chayanov's utopia.

The conference was closed by its three organizers - Alexander Nikulin, Nataliya Mikhalenko and Eliane Fitzé, who hoped for further productive cooperation.

\section{Александр Чаянов: дифференциация и интеграция экономики и политики, науки и искусства}

Элиан Фитзе, аспирантка кафедры славянской литературы в Университете Фрибург (Швейцария). Рю ду Крибле 13, 1700 Фрибург, Швейцария. E-mail: eliane.fitze@unifr.ch 